\section{KEWAJIBAN PENANGGUNG JAWAB ALAT ANGKUT YANG MASUK ATAU KELUAR WILAYAH INDONESIA MENURUT UNDANG-UNDANG NOMOR 6 TAHUN 2011 TENTANG KEIMIGRASIAN ${ }^{1}$ \\ Oleh: Jeremy Oroh ${ }^{2}$}

\begin{abstract}
ABSTRAK
Penelitian ini dilakukan dengan tujuan untuk mengetahui bagaimana kewajiban penanggung jawab alat angkut yang masuk atau keluar wilayah Indonesia dan bagaimana wewenang pejabat imigrasi untuk melakukan pemeriksaan keimigrasian terhadap alat angkut yang masuk atau keluar wilayah Indonesia. Dengan menggunakan metode peneltian yuridis normatif, disimpulkan: $1 . \quad$ Kewajiban penanggung jawab alat angkut yang masuk atau keluar wilayah Indonesia dengan alat angkutnya wajib melalui tempat pemeriksaan imigrasi. Bagi penanggung jawab alat angkut yang membawa penumpang yang akan masuk atau keluar wilayah Indonesia hanya dapat menurunkan atau menaikkan penumpang di tempat pemeriksaan imigrasi dan Nakhoda kapal laut wajib melarang orang asing yang tidak memenuhi persyaratan untuk meninggalkan alat angkutnya selama alat angkut tersebut berada di Wilayah Indonesia. 2 . Wewenang pejabat imigrasi untuk melakukan pemeriksaan keimigrasian terhadap alat angkut yang masuk atau keluar wilayah Indonesia dilakukan dengan cara pejabat imigrasi yang bertugas berwenang naik ke alat angkut yang berlabuh di pelabuhan, mendarat di bandar udara, atau berada di pos lintas batas untuk kepentingan pemeriksaan Keimigrasian. Dalam hal terdapat dugaan adanya pelanggaran terhadap ketentuan hukum, maka pejabat imigrasi berwenang memerintahkan penanggung jawab alat angkut untuk menghentikan atau membawa alat angkutnya ke suatu tempat guna kepentingan pemeriksaan Keimigrasian. Yang dimaksud dengan "suatu tempat" adalah pelabuhan, bandar udara, pos lintas batas atau tempat lainnya yang layak untuk dapat dilakukan pemeriksaan Keimigrasian, sebagaimana diatur
\end{abstract}

\footnotetext{
${ }^{1}$ Artikel Skripsi. Dosen Pembimbing: Harold Anis, SH., MSi, MH; Decky J. Paseki, SH., MH

2 Mahasiswa pada Fakultas Hukum Unsrat, NIM. 16071101377
}

dalam peraturan perundang-undangan di bidang kemigrasian.

Kata kunci: Kewajiban, Penanggung Jawab, Alat Angkut, Masuk Atau Keluar Wilayah Indonesia, Keimigrasian

\section{PENDAHULUAN}

\section{A. Latar Belakang}

Di setiap daerah perbatasan, ada kalanya warga negara yang satu dengan segala kepentingannya harus melewati perbatasan negara untuk mengunjungi negara tetangga mulai dari pejabat, mahasiswa, turis atau penduduk setempat memiliki kepentingan pribadi atau tugas untuk melintas batas negara tersebut. Di setiap negara memiliki hukum dan peraturan masing-masing bagi pelintas batas, biasanya negara yang saling berbatasan membuat MoU (Memorandum of Understanding) atau biasa dikenal nota kesepahaman tentang bagaimana tata cara lintas batas antar negara tersebut, baik untuk berkunjung maupun berdiam sementara. Untuk mengatur hal tersebut, di Indonesia telah terdapat peraturan yang mengaturnya yaitu Undang-undang Republik Indonesia Nomor 6 Tahun 2011 yang menggantikan Undangundang Nomor 9 Tahun 1992 tentang Keimigrasian. ${ }^{3}$

Beberapa kasus pelangaran keimigrasian yang sering dihadapi oleh instansi yang berwenang yaitu seperi: penyalagunaan dokumen perjalanan, penyelundupan narkotika, bahan bakar minyak, senjata api dan penyelundupan orang atau tenaga kerja Indonesia, selain itu terbatasnya sumber daya manusia dan sumber daya energi, sehingga masalah yang timbul menjadi penghambat berjalannya aktivitas pelayanan dan pengawasan terhadap pelintas batas. ${ }^{4}$

Alat Angkut adalah kapal laut, pesawat udara, atau sarana transportasi lain yang lazim digunakan, baik untuk mengangkut orang maupun barang. Sementara itu, yang termasuk Penanggung Jawab Alat Angkut adalah pemilik, pengurus, agen, nakhoda, kapten kapal, kapten

\footnotetext{
${ }^{3}$ Fraquelino Do Rosario Pinto dan Sahudiyono. Pelayanan Dan Pengawasan Terhadap Pelintas Batas Di Pos Lintas Batas Darat Mota'ain Perbatasan Negara Indonesia-Timor Leste. Majalah IImiah Bahari Jogja (MIBJ) Vol. 17 No. 2, Juli 2019. hlm. 11-12.

4 lbid. hlm. 12
} 
pilot, atau pengemudi alat angkut yang bersangkutan. $^{5}$

Semua Penanggung Jawab Alat Angkut yang masuk atau keluar Wilayah Indonesia dengan alat angkutnya wajib melalui Tempat Pemeriksaan Imigrasi. Penanggung Jawab Alat Angkut yang membawa penumpang yang akan masuk atau keluar Wilayah Indonesia hanya dapat menurunkan atau menaikkan penumpang di Tempat Pemeriksaan Imigrasi. ${ }^{6}$ Penanggung Jawab Alat Angkut adalah pemilik, pengurus, agen, nakhoda, kapten kapal, kapten pilot, atau pengemudi alat angkut yang bersangkutan. ${ }^{7}$ Pada setiap Tempat Pemeriksaan Imigrasi ditetapkan suatu area tertentu untuk melakukan pemeriksaan keimigrasian yang merupakan area terbatas dan hanya dapat dilalui oleh pelintas batas yang akan keluar atau masuk wilayah Indonesia atau pejabat dan petugas yang berwenang dan diselenggarakan oleh Kepala Kantor Imigrasi bersama-sama penyelenggara perbatasan negara. (Pasal 22). Kewajiban Penanggung Jawab Alat Angkut: a) Penanggungjawab alat angkut yang masuk atau keluar Wilayah Indonesia dengan alat angkutnya wajib melalui tempat pemeriksaan Imigrasi, b) Penanggungjawab yang membawa alat angkut penumpang yang akan masuk atau keluar Wilayah Indonesia hanya dapat menurunkan atau menaikkan penumpang di Tempat Pemeriksaan Imigrasi. $^{8}$

Aspek pelayanan dan pengawasan tidak pula terlepas dari geografis Wilayah Indonesia yang terdiri atas pulau-pulau yang mempunyai jarak yang dekat, bahkan berbatasan langsung dengan negara tetangga, yang pelaksanaan Fungsi Keimigrasian di sepanjang garis perbatasan merupakan kewenangan instansi imigrasi. Pada tempat tertentu sepanjang garis perbatasan terdapat lalu lintas tradisional masuk dan keluar warga negara Indonesia dan warga negara tetangga. Dalam rangka meningkatkan pelayanan dan memudahkan

\footnotetext{
${ }^{5}$ https://ridwanbahasa.wordpress.com/2019/01/20/kewaj iban-alat-angkut-masuk-dan-keluar.Diakses 10/27/2019 3:42 Wita.

${ }^{6}$ Ibid.

7 Pasal 1 angka 37. Undang-Undang Nomor 6 Tahun 2011 tentang Keimigrasian.

8 Fraquelino Do Rosario Pinto dan Sahudiyono. Op.Cit. hlm. 14. (Lihat Pasal 22 Undang-Undang Nomor 6 Tahun 2011 tentang Keimigrasian. Area Imigrasi).
}

pengawasan dapat diatur perjanjian lintas batas dan diupayakan perluasan Tempat Pemeriksaan Imigrasi. Dengan demikian, dapat dihindari orang masuk atau keluar Wilayah Indonesia di Iuar Tempat Pemeriksaan Imigrasi. ${ }^{9}$

Kasus-kasus yang selama ini banyak terjadi di perbatasan pada dasarnya dapat dikategorikan menjadi: 1) Pelanggaran prosedur keimigrasian, yaitu pelintas batas secara ilegal. Masalah ini juga yang berekses pada banyaknya jumlah TKI bermasalah di Malaysia dan menyelundupnya pelaku kejahatan/teroris. 2) Penyelundupan barang/orang secara illegal. Kasus ini sekarang ini berkembang dalam bentuk trafficking (wanita dan anak-anak) dan perdagangan barang-barang "haram" (narkotika dan obat terlarang). 3) Pencurian sumber daya alam pada wilayah-wilayah yang sulit atau jauh dari jangkauan pengawasan, misalnya pembalakan hutan secara ilegal, pencurian ikan dan sumber daya laut lain 4) Pemidahan tanda-tanda (patok) batas wilayah yang sangat sederhana oleh orang-orang yang tidak bertanggung jawab. 5) Meningkatnya kriminalitas, pencurian hasil bumi, ternak, kendaraan bermotor yang kemudian diselundupkan lewat jalan tikus baik ke luar maupun ke wilayah RI. ${ }^{10}$

\section{B. RUMUSAN MASALAH}

1. Bagaimanakah kewajiban penanggung jawab alat angkut yang masuk atau keluar wilayah Indonesia?

2. Bagaimanakah wewenang pejabat imigrasi untuk melakukan pemeriksaan keimigrasian terhadap alat angkut yang masuk atau keluar wilayah Indonesia ?

\section{METODE PENELITIAN}

Metode penelitian digunakan dalam suatu penelitian ilmiah. Penelitian ilmiah ialah penalaran yang mengikuti suatu alur berfikir atau logika yang tertentu dan yang menggabungkan metode induksi (empiris), karena penelitian ilmiah selalu menuntut pengujian dan pembuktian empiris dan

\footnotetext{
9 Penjelasan Atas Undang-Undang Nomor 6 Tahun 2011 tentang Keimigrasian.

${ }^{10}$ Fraquelino Do Rosario Pinto dan Sahudiyono. Op.Cit. hlm. 21-22.
} 
hipotesis-hipotesis atau teori yang disusun secara deduktif. ${ }^{11}$

Metode penelitian normatif disebut juga sebagai penelitian doctrinal (doctrinal research) yaitu suatu penelitian yang menganalisis hukum baik yang tertulis didalam buku (law as it is written in the book), maupun hukum yang diputuskan oleh hakim melalui proses pengadilan (law it is decided by the judge through judicial process). ${ }^{12}$

Penelitian hukum yang dilakukan dengan cara meneliti bahan pustaka atau data sekunder belaka, dapat dinamakan penelitian hukum normatif atau penelitian hukum kepustakaan (di samping adanya penelitian hukum sosiologis atau empiris yang terutama meneliti data primer). ${ }^{13}$

Metode yang digunakan adalah metode penelitian normatif yang merupakan prosedur penelitian ilmiah untuk menemukan kebenaran berdasarkan logika keilmuan hukum dari sisi normatifnya. ${ }^{14}$ Pendekatan yang digunakan adalah pendekatan perundang-undangan (statute approach)..$^{15}$

\section{PEMBAHASAN}

A. Kewajiban Penanggung Jawab Alat Angkut Yang Masuk Atau Keluar Wilayah Indonesia

Istilah imigrasi berasal dari bahasa belanda, yaitu immigratie, sedangkan bahasa Latin, yaitu immigrate, dengan kata kerjanya immigreren, yang dalam bahasa Latinnya disebut immigratie. Dalam bahasa Inggris disebut immigration yang terdiri dari dua kata yaitu, in artinya "dalam" dan migrasi artinya "pindah, datang, masuk atau boyong". ${ }^{16}$

Undang-Undang Nomor 6 Tahun 2011 Tentang Keimigrasian, mengatur mengenai Kewajiban Penanggung Jawab Alat Angkut. Pasal 17 ayat:

\footnotetext{
${ }^{11}$ Sunaryati Hartono, Penelitian Hukum di Indonesia Pada Akhir Abad ke-20. Rineka Cipta, Bandung. 1994, hlm. 105. ${ }^{12}$ Amiruddin dan Zainal Asikin, Pengantar Metode Penelitian Hukum, Grafitti Press. Jakarta. 2006. hlm. 118. ${ }^{13}$ Soerjono Soekanto dan Sri Mamudji, Penelitian Hukum Normatif Suatu Tinjauan Singkat, PT Raja Grafindo Persada, Jakarta. 1995, hlm. 13-14.

14 Johnny Ibrahim, Teori dan Metodologi Penelitian Hukum Normatif. Citra Aditya Bakti. Bandung. 2007. hlm. 57.

$15 \mathrm{lbid}$. hlm. 302.

${ }^{16}$ Sihar Sihombing. Hukum Imigrasi. Nuansa Aulia.

Bandung. 2006. hlm.2.
}

(1) Penanggung Jawab Alat Angkut yang masuk atau keluar Wilayah Indonesia dengan alat angkutnya wajib melalui Tempat Pemeriksaan Imigrasi.

(2) Penanggung Jawab Alat Angkut yang membawa penumpang yang akan masuk atau keluar Wilayah Indonesia hanya dapat menurunkan atau menaikkan penumpang di Tempat Pemeriksaan Imigrasi.

(3) Nakhoda kapal laut wajib melarang Orang Asing yang tidak memenuhi persyaratan untuk meninggalkan alat angkutnya selama alat angkut tersebut berada di Wilayah Indonesia.

Pasal 18 ayat:

(1) Penanggung Jawab Alat Angkut yang datang dari luar Wilayah Indonesia atau akan berangkat keluar Wilayah Indonesia diwajibkan untuk:

a. sebelum kedatangan atau keberangkatan memberitahukan rencana kedatangan atau rencana keberangkatan secara tertulis atau elektronik kepada Pejabat Imigrasi;

b. menyampaikan daftar penumpang dan daftar awak alat angkut yang ditandatanganinya kepada Pejabat Imigrasi;

c. memberikan tanda atau mengibarkan bendera isyarat bagi kapal laut yang datang dari luar Wilayah Indonesia dengan membawa penumpang;

d. melarang setiap orang naik atau turun dari alat angkut tanpa izin Pejabat Imigrasi sebelum dan selama dilakukan pemeriksaan Keimigrasian;

e. melarang setiap orang naik atau turun dari alat angkut yang telah mendapat penyelesaian Keimigrasian selama menunggu keberangkatan;

f. membawa kembali keluar Wilayah Indonesia pada kesempatan pertama setiap Orang Asing yang tidak memenuhi persyaratan yang datang dengan alat angkutnya;

g. menjamin bahwa Orang Asing yang diduga atau dicurigai akan masuk ke Wilayah Indonesia secara tidak sah untuk tidak turun dari alat angkutnya; dan

h. menanggung segala biaya yang timbul sebagai akibat pemulangan setiap 
penumpang dan/atau awak alat angkutnya.

(2) Penanggung Jawab Alat Angkut reguler wajib menggunakan sistem informasi pemrosesan pendahuluan data penumpang dan melakukan kerja sama dalam rangka pemberitahuan data penumpang melalui Sistem Informasi Manajemen Keimigrasian.

Penjelasan Pasal 18 ayat (1) huruf c Yang dimaksud dengan "memberikan tanda atau mengibarkan bendera isyarat" adalah antara lain mengibarkan bendera " $\mathrm{N}$ " yang biasa digunakan dalam kebiasaan internasional. Huruf (h) Dalam ketentuan ini yang dimaksud dengan "setiap penumpang dan/atau awak alat angkut" antara lain penumpang yang tidak mendapat Tanda Masuk, awak kapal, atau penumpang yang tertinggal. Ayat (2) Sistem Informasi Pemrosesan Pendahuluan Data Penumpang lazim juga disebut dengan Advance Passenger Information System. Terhadap alat angkut yang belum menggunakan Sistem Informasi Pemrosesan Pendahuluan Data Penumpang, diberikan kesempatan sampai dengan batas waktu tertentu. Pasal 19 ayat:

(1) Penanggung Jawab Alat Angkut wajib memeriksa Dokumen Perjalanan dan/atau Visa setiap penumpang yang akan melakukan perjalanan masuk Wilayah Indonesia.

(2) Pemeriksaan sebagaimana dimaksud pada ayat (1) dilakukan sebelum penumpang naik ke alat angkutnya yang akan menuju Wilayah Indonesia.

(3) Penanggung Jawab Alat Angkut sebagaimana dimaksud pada ayat (1) wajib menolak untuk mengangkut setiap penumpang yang tidak memiliki Dokumen Perjalanan, Visa, dan/atau Dokumen Keimigrasian yang sah dan masih berlaku.

(4) Jika dalam pemeriksaan Keimigrasian oleh Pejabat Imigrasi ditemukan ada penumpang sebagaimana dimaksud pada ayat (3), Penanggung Jawab Alat Angkut dikenai sanksi berupa biaya beban dan wajib membawa kembali penumpang tersebut keluar Wilayah Indonesia.

Sebelum masuk dan keluar wilayah Indonesia, ada beberapa kewajiban penanggung jawab alat angkut yang harus dilakukan. Penanggung Jawab Alat Angkut yang datang dari luar Wilayah Indonesia atau akan berangkat keluar Wilayah Indonesia diwajibkan untuk:

1. sebelum kedatangan atau keberangkatan memberitahukan rencana kedatangan atau rencana keberangkatan secara tertulis atau elektronik kepada Pejabat Imigrasi;

2. menyampaikan daftar penumpang dan daftar awak alat angkut yang ditandatanganinya kepada Pejabat Imigrasi;

3. memberikan tanda atau mengibarkan bendera isyarat bagi kapal laut yang datang dari luar Wilayah Indonesia dengan membawa penumpang;

4. melarang setiap orang naik atau turun dari alat angkut tanpa izin Pejabat Imigrasi sebelum dan selama dilakukan pemeriksaan Keimigrasian;

5. melarang setiap orang naik atau turun dari alat angkut yang telah mendapat penyelesaian Keimigrasian selama menunggu keberangkatan;

6. membawa kembali keluar Wilayah Indonesia pada kesempatan pertama setiap Orang Asing yang tidak memenuhi persyaratan yang datang dengan alat angkutnya;

7. menjamin bahwa Orang Asing yang diduga atau dicurigai akan masuk ke Wilayah Indonesia secara tidak sah untuk tidak turun dari alat angkutnya;

8. menanggung segala biaya yang timbul sebagai akibat pemulangan setiap penumpang dan/atau awak alat angkutnya. ${ }^{17}$

Kantor Imigrasi Kelas II TPI Tembilahan gelar Sosialisasi Keimigrasian Pengenaan Biaya Beban Terhadap Penanggungjawab Alat Angkut. Sosialisasi diadakan dalam rangka meningkatkan pemahaman penanggung jawab alat angkut yang masuk dan keluar wilayah Indonesia serta sebagai upaya dalam meningkatkan pengawasan terhadap lalu lintas keluar masuk alat angkut di wilayah Indonesia, terutama di Kabupaten Indragiri Hilir. Kepala Kantor Imigrasi Kelas II TPI Tembilahan, Najarudin Safaat, menjelaskan bahwa biaya beban dikenakan kepada penanggung jawab alat angkut apabila membawa penumpang atau awak alat angkut yang tidak memiliki dokumen perjalanan, tidak memiliki visa dan/ atau tidak

\footnotetext{
${ }^{17}$ https://ridwanbahasa.wordpress.com/2019/01/20/kewa jiban-alat-angkut-masuk-dan-keluar.Diakses 10/27/2019 3:42 Wita.
} 
memiliki dokumen keimigrasian yang sah dan masih berlaku sebagaimana tertuang dalam Pasal 19 UU No. 6 Tahun 2011 tentang Keimigrasian. ${ }^{18}$

\section{B. Wewenang Pejabat Imigrasi Untuk Melakukan Pemeriksaan Keimigrasian Terhadap Alat Angkut Yang Masuk Atau Keluar Wilayah Indonesia}

Kedaulatan teritorial adalah kekuasaan penuh yang dimiliki oleh suatu negara dalam hal melaksanakan jurisdiksi (kewenangan) secara eksklusif di wilayahnya, yang mana di dalam wilayah tersebut negara memiliki kewenangan penuh untuk melaksanakan dan menegakkan hukum nasionalnya (exercise and enforce (aw). Hal ini menandakan bahwa setiap individu yang mendiami suatu wilayah tertentu haruslah tunduk dan patuh kepada kekuasaan hukum dari negara yang memiliki wilayah tersebut. ${ }^{19}$

Tempat Pemeriksaan Imigrasi atau disingkat (TPI) adalah tempat pemeriksaan di pelabuhan laut, Bandar udara, pos lintas batas, atau tempat lain sebagai tempat masuk dan keluar wilayah Indonesia. TPI merupakan pintu gerbang Indonesia bagi Orang Asing, WNI, awak alat angkut, alat angkut, barang dari seluruh dunia untuk masuk dan keluar wilayah Indonesia. Titik masuk dan keluar (points of entry/ points of exit) ini tidak hanya di pelabuhan, bandara dan darat, tetapi juga ada tempat lain yang ditunjuk oleh Menteri melalui Direktur Jenderal Imigrasi. TPI tempat lain dapat berupa tempat pemeriksaan di atas alat angkut (clearance on board) yakni Immigration on Board (IOB) pada pesawat terbang, dan Immigration on Shipping atau di atas kapal laut/ alat apung. Tempat lain sebagai TPI juga dapat berupa tempat darurat saat alat angkut datang, mendarat, sandar karena keadaan darurat. ${ }^{20}$

Undang-Undang Nomor 6 Tahun 2011 Tentang Keimigrasian, mengatur mengenai

\footnotetext{
${ }^{18} \mathrm{https}: / /$ detikriau.org/category/pro-otonomi/inhil/Kantor Imigrasi Kelas II TPI Sosialisasikan Keimigrasian Pengenaan Biaya Beban Terhadap Penanggungjawab Alat Angkut. Diakses 10/27/2019 4:09 Wita.

${ }^{19}$ Huala Adolf, Aspek-Aspek Negara Dalam Hukum Internasional, Keni Media Bandung. 2011. hlm. 115. ${ }^{20}$ https://ridwanbahasa.wordpress.com/2019/01/20/kewa jiban-alat-angkut-masuk-dan-keluar.Diakses 10/27/2019 3:42 Wita.
}

Area Imigrasi sebagaimana dinyatakan dalam Pasal 22 ayat:

(1) Setiap Tempat Pemeriksaan Imigrasi ditetapkan suatu area tertentu untuk melakukan pemeriksaan Keimigrasian yang disebut dengan area imigrasi.

(2) Area imigrasi merupakan area terbatas yang hanya dapat dilalui oleh penumpang atau awak alat angkut yang akan keluar atau masuk Wilayah Indonesia atau pejabat dan petugas yang berwenang.

(3) Kepala Kantor Imigrasi bersama-sama dengan penyelenggara bandar udara, pelabuhan laut, dan pos lintas batas menetapkan area imigrasi sebagaimana dimaksud pada ayat (1).

(4) Penyelenggara bandar udara, pelabuhan laut, dan pos lintas batas dapat mengeluarkan tanda untuk memasuki area imigrasi setelah mendapat persetujuan kepala Kantor Imigrasi.

Penjelasan Pasal 22 ayat (1) Yang dimaksud dengan "area imigrasi" adalah suatu area di Tempat Pemeriksaan Imigrasi, yang dimulai dari tempat antrean pemeriksaan Keimigrasian pada keberangkatan sampai dengan alat angkut atau dari alat angkut sampai dengan konter pemeriksaan Keimigrasian pada kedatangan. Penetapan area imigrasi sangat penting artinya untuk menentukan status seseorang apakah telah dianggap keluar atau telah masuk Wilayah Indonesia. Ayat (3) Kepala Kantor Imigrasi dalam ketentuan ini membawahi Tempat Pemeriksaan Imigrasi pada bandar udara, pelabuhan laut, atau pos lintas batas. Ayat (4) Ketentuan ini dilaksanakan berdasarkan asas resiprositas apabila diberikan kepada orang asing dalam rangka tugas diplomatik.

Pasal 23. Ketentuan lebih lanjut mengenai persyaratan dan tata cara masuk dan keluar Wilayah Indonesia diatur dengan Peraturan Pemerintah. Hukum keimigrasian adalah himpunan petunjuk yang mengatur tata tertib orang-orang yang berlalu lintas dalam wilayah Indonesia dan pengawasan terhadap orangorang asing yang berada diwilayah Indonesia. Hukum keimigrasian termasuk dalam hukum publik yaitu hukum yang mengatur hubungan antara individu dengan negara (pemerintah). ${ }^{21}$ Pengaturan bidang keimigrasian

${ }^{21}$ Abdullah Sjahriful. 1993. Op.Cit. hlm. 58. 
(lalu lintas keluar masuk) suatu negara, berdasarkan hukum internasional merupakan hak dan wewenang suatu negara. ${ }^{22}$

Pengaturan keimigrasian yang meliputi lalulintas orang masuk atau ke luar wilayah Indonesia, merupakan hak dan wewenang negara Republik Indonesia serta merupakan salah satu perwujudan dari kedaulatannya sebagai negara hukum. Makna keimigrasian bagi warga negara adalah setiap warga negara berhak melakukan perjalanan masuk dan keluar wilayah Indonesia. ${ }^{23}$

Masuk dan keluar wilayah Indonesia, maka setiap orang yang masuk atau ke luar wilayah Indonesia wajib memiliki surat perjalanan. Setiap orang dapat ke luar wilayah Indonesia, apabila telah mendapat tanda bertolak, yakni tanda tertentu yang diterakan oleh pejabat imigrasi di tempat pemeriksaan imigrasi dalam surat perjalanan setiap orang yang akan masuk ke Indonesia setelah mendapat izin yang diberikan pada visa atau surat perjalanan untuk memasuki wilayah Indonesia yang diberikan oleh pejabat imigrasi di tempat pemeriksaan imigrasi. Setiap orang asing yang masuk ke wilayah Indonesia, wajib memiliki visa. Visa diberikan kepada orang asing yang maksud dan tujuan kedatangannya di Indonesia bermanfaat serta tidak akan menimbulkan gangguan terhadap ketertiban dan keamanan nasional. ${ }^{24}$

Kepentingan nasional adalah kepentingan seluruh rakyat Indonesia sehingga pengawasan terhadap Orang Asing memerlukan juga partisipasi masyarakat untuk melaporkan Orang Asing yang diketahui atau diduga berada di Wilayah Indonesia secara tidak sah atau menyalahgunakan perizinan di bidang Keimigrasian. Untuk meningkatkan partisipasi masyarakat, perlu dilakukan usaha untuk meningkatkan kesadaran hukum masyarakat. Berdasarkan kebijakan selektif (selective policy) yang menjunjung tinggi nilai hak asasi manusia, diatur masuknya Orang Asing ke dalam Wilayah Indonesia, demikian pula bagi Orang Asing yang memperoleh Izin Tinggal di Wilayah Indonesia harus sesuai dengan maksud dan tujuannya berada di Indonesia. ${ }^{25}$

\footnotetext{
${ }^{22}$ Ramadhan. K.H. dan Abrar Yusra. Op.Cit. hlm. 12.

23 Siswanto Sunarso. Op.Cit, hlm. 203.

24 Ibid.

25 Penjelasan Atas Undang-Undang Nomor 6 Tahun 2011 tentang Keimigrasian.
}

Berdasarkan kebijakan dimaksud serta dalam rangka melindungi kepentingan nasional, hanya Orang Asing yang memberikan manfaat serta tidak membahayakan keamanan dan ketertiban umum diperbolehkan masuk dan berada di Wilayah Indonesia. Terhadap warga negara Indonesia berlaku prinsip bahwa setiap warga negara Indonesia berhak untuk keluar atau masuk Wilayah Indonesia. Namun, berdasarkan alasan tertentu dan untuk jangka waktu tertentu warga negara Indonesia dapat dicegah keluar dari Wilayah Indonesia. Warga negara Indonesia tidak dapat dikenai tindakan Penangkalan karena hal itu tidak sesuai dengan prinsip dan kebiasaan internasional, yang menyatakan bahwa seorang warga negara tidak boleh dilarang masuk ke negaranya sendiri. ${ }^{26}$

Di samping permasalahan di atas, terdapat beberapa hal yang menjadi pertimbangan untuk memperbarui Undang-Undang Nomor 9 Tahun 1992 tentang Keimigrasian, yakni:

a. letak geografis Wilayah Indonesia dengan kompleksitas permasalahan lalu lintas antarnegara terkait erat dengan aspek kedaulatan negara dalam hubungan dengan negara lain;

b. adanya perjanjian internasional atau konvensi internasional yang berdampak langsung atau tidak langsung terhadap pelaksanaan Fungsi Keimigrasian;

c. meningkatnya kejahatan internasional dan transnasional, seperti imigran gelap, Penyelundupan Manusia, perdagangan orang, terorisme, narkotika, dan pencucian uang;

d. pengaturan mengenai Deteni dan batas waktu terdeteni belum dilakukan secara komprehensif;

e. Fungsi Keimigrasian yang spesifik dan bersifat universal dalam pelaksanaannya memerlukan pendekatan sistematis dengan memanfaatkan teknologi informasi dan komunikasi yang modern, dan memerlukan penempatan struktur Kantor Imigrasi dan Rumah Detensi Imigrasi sebagai unit pelaksana teknis berada di bawah Direktorat Jenderal Imigrasi;

f. perubahan sistem kewarganegaraan Republik Indonesia berdasarkan UndangUndang Nomor 12 Tahun 2006 tentang

\footnotetext{
26 Ibid.
} 
Kewarganegaraan Republik Indonesia berkaitan dengan pelaksanaan Fungsi Keimigrasian, antara lain mengenai berkewarganegaraan ganda terbatas;

g. hak kedaulatan negara dalam penerapan prinsip timbal balik (resiprositas) mengenai pemberian Visa terhadap Orang Asing;

h. kesepakatan dalam rangka harmonisasi dan standardisasi sistem dan jenis pengamanan surat perjalanan secara internasional, khususnya Regional Asean Plus dan juga upaya penyelarasan atau harmonisasi tindakan atau ancaman pidana terhadap para pelaku sindikat yang mengorganisasi perdagangan orang dan Penyelundupan Manusia;

i. penegakan hukum Keimigrasian belum efektif sehingga kebijakan pemidanaan perlu mencantumkan pidana minimum terhadap tindak pidana Penyelundupan Manusia;

j. memperluas subjek pelaku tindak pidana Keimigrasian, sehingga mencakup tidak hanya orang perseorangan tetapi juga Korporasi serta Penjamin masuknya Orang Asing ke Wilayah Indonesia yang melanggar ketentuan Keimigrasian; dan

k. penerapan sanksi pidana yang lebih berat terhadap Orang Asing yang melanggar peraturan di bidang Keimigrasian karena selama ini belum menimbulkan efek jera.

Dengan adanya pertimbangan tersebut di atas, perlu dilaksanakan pembaruan terhadap UndangUndang Nomor 9 Tahun 1992 dengan membentuk undang-undang baru yang lebih komprehensif, guna menyesuaikan dengan perkembangan kemasyarakatan dan kenegaraan Indonesia, kebijakan atau peraturan perundang-undangan terkait, serta bersifat antisipatif terhadap permasalahan di masa depan. ${ }^{27}$

Menurut Kansil dalam pergaulan masyarakat terdapat aneka macam hubungan di antara anggota masyarakat, yakni hubungan yang ditimbulkan oleh kepentingan-kepentingan anggota masyarakat itu, karena beraneka ragamnya hubungan itu, para anggota masyarakat memerlukan aturan-aturan yang dapat menjamin keseimbangan agar dalam

\footnotetext{
27 Ibid.
}

hubungan-hubungan itu tidak terjadi kekacauan di dalam masyarakat. ${ }^{28}$

Peraturan-peraturan hukum yang bersifat mengatur dan memaksa anggota masyarakat untuk patuh dalam menaatinya akan menciptakan keseimbangan dalam setiap hubungan di dalam masyarakat. Setiap pelanggaran atas peraturan yang ada akan dikenakan sanksi atau hukuman sebagai reaksi terhadap perbuatan yang melanggar peraturan. ${ }^{29}$

Untuk menjaga agar peraturan-peraturan itu dapat berlangsung terus-menerus dan diterima oleh seluruh anggota masyarakat, aturan hukum yang ada harus sesuai dan tidak boleh bertentangan dengan rasa keadilan masyarakat. Dengan demikian, hukum bertujuan untuk menjamin adanya kepastian hukum dalam masyarakat dan harus bersendikan pada keadilan yaitu rasa keadilan masyarakat. ${ }^{30}$

Empat pendapat mengenai Admission atau izin masuk bagi orang asing ke negara-negara bukan negara mereka:

a. Suatu negara berkewajiban memberi izin kepada semua orang asing;

b. Suatu negara berkewajiban memberikan izin kepada orang asing dengan syarat negara tersebut berhak menolak golongan tertentu;

c. Suatu negara terikat untuk mengizinkan orang asing untuk masuk tetapi dapat mengenakan syarat-syarat yang berkenaan dengan izin masuk mereka;

d. Suatu negara sepenuhnya berhak melarang semua orang asing menurut kehendaknya. ${ }^{31}$

Sejauh praktek negara, pendapat pertama (a) tidak pernah dijadikan sebagai suatu kaidah hukum internasional. Setiap negara memiliki kedaulatan teritorial menyangkut pemberian hukum internasional, termasuk mengenai pengusiran terhadap orang asing. Biasanya traktat-traktat yang dibuat antar negara-negara yang bersangkutan menjadi petunjuk pelaksanaan hal tersebut. ${ }^{32}$

Terhadap warga negara Indonesia berlaku prinsip bahwa setiap warga negara Indonesia

\footnotetext{
${ }^{28}$ Arus Akbar Silondae dan Wirawan B. Ilyas. Pokok-Pokok Hukum Bisnis. Salemba Empat. Jakarta. 2011. hlm. 3.

29 lbid.

$30 \mathrm{lbid}$.

${ }^{31} \mathrm{~T}$. May Rudy, Hukum Internasional 1. Cetakan Ketiga, PT. Refika Aditama, Bandung. 2010, hlm. 63.

32 Ibid.
} 
berhak untuk keluar atau masuk Wilayah Indonesia. Namun, berdasarkan alasan tertentu dan untuk jangka waktu tertentu warga negara Indonesia dapat dicegah keluar dari Wilayah Indonesia. Warga negara Indonesia tidak dapat dikenai tindakan Penangkalan karena hal itu tidak sesuai dengan prinsip dan kebiasaan internasional, yang menyatakan bahwa seorang warga negara tidak boleh dilarang masuk ke negaranya sendiri. ${ }^{33}$

Tatacara penindakan keimigrasian ditetapkan dengan keputusan tertulis oleh pejabat Imigrasi yang berwenang dan disampaikan selambat-lambatnya tujuh hari terhitung sejak tanggal penetapan kepada orang asing yang dikenakan tindakan. Setiap orang asing yang terkena tindakan dapat mengajukan keberatan kepada Menteri dalam jangka waktu tiga hari sejak tanggal diterimanya keputusan tindakan keimigrasian tersebut. Tindakan keimigrasian dapat pula dilakukan secara tindakan administratif di bidang keimigrasian di luar proses peradilan dan ditetapkan secara tertulis. ${ }^{34}$

Orang asing dapat ditempatkan di dalam karantina imigrasi dengan alasan-alasan bahwa: berada di wilayah negara republik Indonesia tanpa memiliki izin proses pengusiran atau deportasi atau dalam rangka menunggu keputusan Menteri mengenai pengajuan keberatan yang dilakukan termasuk terhadap orang yang dikenakan tindakan administratif. ${ }^{35}$

\section{PENUTUP}

\section{A. Kesimpulan}

1. Kewajiban penanggung jawab alat angkut yang masuk atau keluar wilayah Indonesia dengan alat angkutnya wajib melalui tempat pemeriksaan imigrasi. Bagi penanggung jawab alat angkut yang membawa penumpang yang akan masuk atau keluar wilayah Indonesia hanya dapat menurunkan atau menaikkan penumpang di tempat pemeriksaan imigrasi dan Nakhoda kapal laut wajib melarang orang asing yang tidak memenuhi persyaratan untuk meninggalkan alat angkutnya selama alat

\footnotetext{
33 Penjelasan Atas Undang-Undang Nomor 6 Tahun 2011 tentang Keimigrasian.

${ }^{34}$ Siswanto Sunarso, Op.Cit. hlm. 207.

$35 \mathrm{Ibid}$, hlm. 207-208.
}

angkut tersebut berada di Wilayah Indonesia.

2. Wewenang pejabat imigrasi untuk melakukan pemeriksaan keimigrasian terhadap alat angkut yang masuk atau keluar wilayah Indonesia dilakukan dengan cara pejabat imigrasi yang bertugas berwenang naik ke alat angkut yang berlabuh di pelabuhan, mendarat di bandar udara, atau berada di pos lintas batas untuk kepentingan pemeriksaan Keimigrasian. Dalam hal terdapat dugaan adanya pelanggaran terhadap ketentuan hukum, maka pejabat imigrasi berwenang memerintahkan penanggung jawab alat angkut untuk menghentikan atau membawa alat angkutnya ke suatu tempat guna kepentingan pemeriksaan Keimigrasian. Yang dimaksud dengan "suatu tempat" adalah pelabuhan, bandar udara, pos lintas batas atau tempat lainnya yang layak untuk dapat dilakukan pemeriksaan Keimigrasian, sebagaimana diatur dalam peraturan perundang-undangan di bidang kemigrasian.

\section{B. Saran}

1. Pelaksanaan kewajiban penanggung jawab alat angkut yang masuk atau keluar wilayah Indonesia wajib menggunakan sistem informasi pemrosesan pendahuluan data penumpang dan melakukan kerja sama dalam rangka pemberitahuan data penumpang melalui sistem informasi manajemen keimigrasian dan memeriksa Dokumen Perjalanan dan/atau visa setiap penumpang yang akan melakukan perjalanan masuk wilayah Indonesia.

2. Pelaksanaan wewenang pejabat imigrasi untuk melakukan pemeriksaan keimigrasian terhadap alat angkut yang masuk atau keluar wilayah Indonesia memerlukan kerjasama antara kepala kantor Imigrasi dengan penyelenggara bandar udara, pelabuhan laut, dan pos lintas batas untuk menetapkan area imigrasi. Penyelenggara bandar udara, pelabuhan laut, dan pos lintas batas dapat mengeluarkan tanda untuk memasuki area imigrasi setelah 
mendapat persetujuan kepala Kantor Imigrasi.

\section{DAFTAR PUSTAKA}

Adolf Huala, Aspek-Aspek Negara Dalam Hukum Internasional, Keni Media Bandung. 2011.

Amiruddin dan Zainal Asikin, Pengantar Metode Penelitian Hukum, Grafitti Press. Jakarta. 2006.

Atmasasmita Romli, Pengantar Hukum Pidana Internasional, Refika Aditama, Cetakan, Pertama. Bandung. 2000.

Efendi Marwan. Kejaksaan RI: Posisi dan Fungsinya dari Perspektif Hukum. PT Gramedia Pustaka Utama. Jakarta, 2005.

Fahroy Ali Caesar. Aspek Hukum Internasional Pada Batas "Imajiner"Negara. Jurnal Wawasan Yuridika. Vol. 1 | No. 1 | Maret 2017.

Hariri Muhwan Wawan. Pengantar Ilmu Hukum, Cet. 1. CV. Pustaka Setia Bandung. 2012.

Hartono Sunaryati, Penelitian Hukum di Indonesia Pada Akhir Abad ke-20. Rineka Cipta, Bandung. 1994.

Husni Lalu, Pengantar Hukum Ketenagakerjaan Indonesia, Edisi Revisi, PT. RajaGrafindo, Jakarta, 2008.

Ibrahim Johnny, Teori dan Metodologi Penelitian Hukum Normatif. Citra Aditya Bakti. Bandung. 2007.

K.H. Ramadhan. dan Abrar Yusra. Lintas Sejarah Imigrasi Indonesia. Direktorat Jenderal Imigrasi Departemen Hukum dan HAM. RI. Jakarta. 2005.

Marbun SF.Pokok-Pokok Hukum Administrasi Negara. Liberty. Yogyakarta. 1997.

Marpaung Leden. Asas-Teori-Praktik Hukum Pidana. Sinar Grafika. Jakarta. 2005.

Masriani Tiena Yulies. Pengantar Hukum Indonesia, Cetakan Kelima, Sinar Grafika, Jakarta. 2009.

Nuh Muhammad. Etika Profesi Hukum. CV. Pustaka Setia. Bandung. 2011.

Parthiana Wayan I., Hukum Pidana Internasional, Cet. I. Yrama Widya, Bandung, 2006.

Pinto Do Rosario Fraquelino dan Sahudiyono. Pelayanan Dan Pengawasan Terhadap Pelintas Batas Di Pos Lintas Batas Darat Mota'ain Perbatasan Negara Indonesia-
Timor Leste. Majalah IImiah Bahari Jogja (MIBJ) Vol. 17 No. 2, Juli 2019.

Rahardjo Satjipto, IImu Hukum, Cetakan ke- IV, PT. Citra Aditya Bakti, Bandung, 2006.

Raharjo Satjipto. Hukum dan Perubahan Sosial Suatu Tinjauan Teoretis Serta Pengalaman-Pengalaman di Indonesia. Cetakan Ketiga Genta Publishing. Yogyakarta. 2009.

Rudy May T., Hukum Internasional 1. Cetakan Ketiga, PT. Refika Aditama, Bandung. 2010.

Sadjijono.Polri Dalam Perkembangan Hukum Di Indonesia, (Editor) M. Khoidin, LaksBang PRESSindo, Yogyakarta. 2008.

Santoso Iman, Perspektif Imigrasi dalam Pembangunan Ekonomi dan Ketahanan Nasional, UI-Press. Jakarta. 2004.

Silondae Akbar Arus dan Wirawan B. Ilyas. Pokok-Pokok Hukum Bisnis. Salemba Empat. Jakarta. 2011.

Sihombing Sihar, Hukum Imigrasi, Nuansa Aulia. Bandung. 2009.

Sjahriful Abdullah, Memperkenalkan Hukum Keimigrasian, Ghalia Indonesia, Jakarta. 1993.

Soekanto Soerjono dan Sri Mamudji, Penelitian Hukum Normatif Suatu Tinjauan Singkat, PT Raja Grafindo Persada, Jakarta. 1995.

Soekanto Soerjono, Pengantar Penelitian Hukum, Grafindo. Jakarta. 2006.

Soekanto Soerjono. Faktor-Faktor Yang Mempengaruhi Penegakan Hukum, PT. RajaGrafindo Persada. Edisi 1. Cet.4. Jakarta. 2002.

Soetoprawiro Koerniatmanto, Hukum Kewarganegaraan dan Keimigrasian Indonesia, PT. Gramedia Pustaka Utama. Jakarta.1994.

Sudarsono, Pengantar Ilmu Hukum, Cetakan Kelima, PT. Rineka Cipta, Jakarta, 2007.

Sunarso Siswanto, Ekstradisi \& Bantuan Timbal Balik Dalam Masalah Pidana Instrumen Penegakan Hukum Pidana Internasional, Rineka Cipta, Jakarta. 2009.

Supriadi dan Alimudin, Hukum Perikanan Indonesia, Cetakan Pertama, Sinar Grafika, Jakarta, 2011.

Syamsuddin Aziz. Tindak Pidana Khusus. Sinar Grafika. Jakarta. 2011.

Thontowi Jawahir. Pengantar Ilmu Hukum. Pustaka Fahima. Yogjakarta. 2007. 
Tutik Triwulan Titik, Pengantar Hukum Perdata di Indonesia, Cetakan Pertama, Jakarta, 2006.

Usman, Aspek-Aspek Hukum Perbankan di Indonesia. Penerbit Gramedia Pustaka Utama. Jakarta. 2001.

Yuwono Soesilo. Penyelesaian Perkara Pidana Berdasarkan Kitab Undang-Undang Hukum Acara Pidana. Alumni. Bandung. 1982.

\section{Peraturan Perundang-Undangan}

Undang-Undang Nomor 6 Tahun 2011 tentang Keimigrasian.

Peraturan Pemerintah Republik Indonesia Nomor 31 Tahun 2013 Tentang Peraturan Pelaksanaan Undang-Undang Nomor 6 Tahun 2011 Tentang Keimigrasian.

\section{Internet}

https://ridwanbahasa.wordpress.com/2019/01 /20/kewajiban-alat-angkut-masuk-dankeluar.Diakses 10/27/2019 3:42 Wita. https://detikriau.org/category/prootonomi/inhil/Kantor Imigrasi Kelas II TPI Sosialisasikan Keimigrasian Pengenaan Biaya Beban Terhadap Penanggungjawab Alat Angkut. Diakses 10/27/2019 4:09 Wita. https://ridwanbahasa.wordpress.com/2019/01 /20/kewajiban-alat-angkut-masuk-dankeluar.Diakses 10/27/2019 3:42 Wita. http://rri.co.id/berita/daerah.html.Imigrasi Entikong Sosialisasikan Aturan Penanggung Jawab Alat Angkut Pelintas Batas. Diakses 10/27/2019 4:14 Wita.

https://suduthukum.com/search/label/hukum. Fungsi Keimigrasian. Diakses 10/27/2019.4:23 Wita.

https://ridwanbahasa.wordpress.com/2019/01 /20/kewajiban-alat-angkut-masuk-dankeluar.Diakses 10/27/2019 3:42 Wita. 